\title{
Evaluation of the protective capacity of new mild Citrus tristeza virus (CTV) isolates selected for a preimmunization program
}

\author{
Carlos Alexandre Zanutto*, Maria Júlia Corazza, William Mário de Carvalho Nunes, Gerd Walter Müller
}

IUEM - Depto. de Agronomia, Núcleo de Pesquisa em Biotecnologia Aplicada, Av. Colombo, 5790 - 87020-900 Maringá, PR - Brasil.

*Corresponding author <cazanutto@uem.br>

Edited by: Luís Eduardo Aranha Camargo

\begin{abstract}
The use of tolerant rootstocks and preimmunization has satisfactorily controlled losses associated with the Citrus tristeza virus (CTV). Several researchers have shown that CTV mild isolates that are selected in the same region where they are used are superior to isolates obtained from other areas. Thus, budwoods of 20 outstanding citrus trees were collected in north and northwestern Paraná state (Brazil) citrus-producing areas and established to be used in a preimmunization program. These budwoods were tested to evaluate the potential protection of the inherently present viral complex. Based on biological indexing and molecular characterization of the capsid protein gene by RFLP (restriction fragment length polymorphism, which indicated that the plants were infected with mild isolates of CTV), some of the selected plants could be used in a preimmunization program. These potentially mild and protective isolates were challenged with severe 'Rolândia' isolate inoculations by grafting and by the brown citrus aphid (Toxoptera citricida Kirkaldy) vector, which was faster in transmitting the virus. Some isolates had a better protective value than others, particularly when challenged with the severe CTV isolate. The SSCP (single strand conformational polymorphism) molecular analysis was an excellent complementary tool for monitoring the performance of the experiments and the stability of the viral complex present in the plants. Isolate number 1 , collected in the municipality of Cruzeiro do Sul (CS-1), was the most promising for protecting commercial Pêra sweet orange (C. sinensis L.) orchards in northern and northwestern Paraná. The Rolândia severe CTV isolate was stable and had a high genetic divergence among the severe isolates used as a control (Capão Bonito and Barão B) and all of the isolates tested. Keywords: SSCP, RFLP, cross-protection, citrus
\end{abstract}

Received January 18, 2012

Accepted November 13, 2012 nately introduced from other states, mainly São Paulo, by propagative material (Carraro et al., 2003; Costa et al., 2010).

To some extent, the introduction of preimmunized materials from other areas has solved this problem. However, in some cases, the cross protected budwood from other regions did not protect the resulting trees (Müller et al., 1999). The best preimmunization results were obtained when the CTV protective isolates were selected in the same region where they were used. For example, the Citrovita clone from the Superplant Programme behaves well in southeast São Paulo, where the Capão Bonito CTV complex occurs (Salibe et al., 1992; Müller et al., 1999). Thus, a preimmunization program was generated to select local mild isolates that would offer good long-term protection against the severe isolates that impact the Pêra sweet orange. This program was implemented in 2003 and their results are presented in this study.

\section{Materials and Methods}

The first step was the selection of the mild isolates, which was carried out in 2003 in four Pêra sweet orange orchards located in the Nova Esperança $\left(23^{\circ} 11^{\prime} 42.2^{\prime \prime}\right.$ S, 52 $\left.12^{\prime} 07.0^{\prime \prime} \mathrm{W}\right)$ and Cruzeiro do Sul (22 $57^{\prime} 34.8^{\prime \prime} \mathrm{S}$, $52^{\circ} 09^{\prime} 35.5^{\prime \prime}$ W) municipalities in the northwest of the state and in the Prado Ferreira $\left(23^{\circ} 02^{\prime} 29.4^{\prime \prime} \mathrm{S}, 51^{\circ} 26^{\prime} 42.8^{\prime \prime}\right.$ W) and Arapongas (23⒉'19.0" S, 51 $\left.25^{\prime} 37.6^{\prime \prime} \mathrm{W}\right) \mathrm{mu}$ - 
nicipalities in the northern part of the state of Paraná, Brazil. These areas were chosen two years earlier as the best in the region for citrus by a commission of citrus experts. Trees older than 10 years were selected, true to type, apparently free from diseases and abnormalities, vigorous in growth, and without stem pitting. In addition, trees were selected by their fruit size and historical productivity (of at least six $40.4 \mathrm{~kg}$ fruit boxes annually). Because the trees were very uniform in the four groves, budwood samples were collected in each grove by randomly choosing five of the best trees. A total of 20 samples were collected.

Budwoods were collected from bearing branches, which is the preferred method to start a preimmunization program (Müller and Rezende, 2004). The collected budwoods were established on Rangpur lime (Citrus limonia Osb.) rootstocks in a greenhouse $\left(23^{\circ} 23^{\prime} 57.8^{\prime \prime} \mathrm{S}\right.$, $\left.51^{\circ} 57^{\prime} 05.3^{\prime \prime} \mathrm{W}\right)$. In addition to the CTV, the plants were indexed for Citrus Variegated Chlorosis (CVC) by using the polymerase chain reaction (PCR). In addition, they were indexed for psorosis and vein enation/woody gall viruses and exocortis and cachexia/xyloporosis viroids using the appropriate indicators (Greve et al., 1991; Carvalho et al., 2003). For biological indexing of CTV, the Mexican lime [C. aurantifolia (Christm.) Swing.]/Rangpur lime indicator combination was used. Evaluation was based on the vein clearing scoring intensity, vein corking, cupping of leaves and growth/vigor of the indicator plant (Carvalho et al., 1997). Stem pitting symptoms were scored according to the diagramatic scale proposed by Meissner-Filho et al. (2002). On this scale, 0 corresponds to the absence of pits; 1 , to rare superficial pits; 2 , to a moderate number of pits; 3 , to an intermediate number of pits (between mild and severe); 4, to many shallow pits with some deep pits; 5 , to the covering of all wood by deep pits.

For the molecular characterization to determine the nature of the CTV isolates present in the selected plants, the restriction fragment length polymorphism (RFLP) technique was used, according to Valverde et al. (1990). This technique converts the fragments obtained from the gels to a binary matrix consisting of the presence or absence of bands. The genetic variability between the CTV isolates of the selected plants was evaluated by the analysis of the main components (PCA - Principal Components Analysis) with the Canoco program in Windows 4.5. From this matrix, a genetic divergency dendogram was generated based on the Euclidian distance. The generation of this dendogram was achieved using the UPGMA (Unweighted Pair-Group Method with Arithmetic Averages) for grouping in the Statistica 6.0 software.

To prepare the plants for the experiment in late 2005, Pêra scions were grafted onto 5-7 mm diameter Rangpur lime rootstocks. The plants were allowed to grow until they reached 50 to $70 \mathrm{~cm}$. The following treatments were used: (i) six combinations for every isolate were prepared for a total of 120 plants; (ii) six combinations of the Pêra IAC clone and six of the Cit- rovita clone were used as mild controls; (iii) for a positive control for severe isolates, six plants were prepared with budwood that came from three plants located in a Rolândia region orchard (north of the state) that showed severe CTV symptoms and had identical electrophorectic profiles. The same was performed for the Capão Bonito CTV complex. The Barão B isolate was also used as a severe control because it is a standard control in experiments conducted in the state of São Paulo. In addition, the CTV isolate of the three Rolândia trees was used as a challenger (Rolândia isolate). The fouth treatment was: six virus-free Pêra plants were used as a negative control. In total, the experiment consisted of 156 plants. All plants were maintained under aphid proof screens.

To test the protective capacity of the selected isolates, they were inoculated with the severe Rolândia isolate. Two challenge methods were employed: inoculation by viruliferous brown citrus aphids and by tissue union (grafting). For the CTV insect challenge, viruliferous brown citrus aphid colonies were reared in cages on the three Rolândia Pêra source trees. After enough insects were found in the caged twigs, they were cut, put in ice chests, and transported to the laboratory. Inoculation was carried out placing twigs and/or leaf pieces that had a mean of 50 insects per plant in two plants of each treatment. After the aphids migrated to the plants, they were allowed to remain for $72 \mathrm{~h}$ in each of the two inoculations. A period of two weeks was used between inoculations to assure that the maximum challenge was achieved. All aphid-challenged plants were isolated by placing them in a cage with an aphid proof screen. At the end of the $72 \mathrm{~h}$-period, the aphids were eliminated with an insecticide spray (Methidathion) and the plants were returned to the greenhouse. For the tissue union challenge, two plants of each treatment were bud inoculated by using two buds of the Rolândia trees that the aphids were reared on. The inoculated buds were allowed to sprout until reaching approximately $20 \mathrm{~cm}$ in length. Once the buds reached $20 \mathrm{~cm}$ in length, they were trimmed.

PCR analyses were performed at 30 days intervals on the negative (healthy) control challenged plants to determine the effectiveness of the aphid and budding challenge inoculations. In addition, this procedure was used to determine the time needed for the effective distribution of the virus in the plant (taking into account the inoculation method). Using this method, it was possible to determine the best moment for collecting material for SSCP analysis. After demonstrating the effective colonization of the virus in the plants, materials from all of the experimental plants were collected for analysis.

Total RNA isolation of the virus was conducted by using the Trizol reagent according to the manufacturer specifications (Life Technologies). The viral RNA served as a template for the synthesis of the first cDNA strand (Sambrook et al., 1989). The CPG amplification by PCR was carried out using two specific primers, including 
CN119 (5'AGA TCT ACC ATG GAC GAC GAA ACA AAG $\left.3^{\prime}\right)$ and CN120 (5'GAA TTC GCG GCT CAA CGT GTG TTA AAT TTC C $\left.3^{\prime}\right)$. The SSCP analyses were performed by following the methodology used by Corazza-Nunes et al. (2001). In this method, the samples were submitted to electrophoresis in an $8 \%$ non denaturing polyacrylamide gel at $25{ }^{\circ} \mathrm{C}$ for $16 \mathrm{~h}$ at a current of $200 \mathrm{~V}$. The gel was stained with silver nitrate (Beidler et al., 1982). The SSCP analyses considered the number and position of the bands. Comparisons were established among the isolates of the same treatment and the Pêra IAC and Citrovita mild controls and the Rolândia, Capão Bonito and Barão B severe controls. The healthy material was used as a negative control (blank) to rule out possible contamination.

The protection of the mild isolates was evaluated under field conditions with high inoculum pressure from the severe isolates. Thus, a replication of the experiment was established in Arapongas, North Paraná. This area $\left(23^{\circ} 24^{\prime} 43^{\prime \prime} \mathrm{S}, 51^{\circ} 30^{\prime} 58^{\prime \prime} \mathrm{W}\right)$ is a commercial orchard with trees that are more than 12 years old. In addition, high severe isolate pressure was previously detected in this orchard (Carrarro et al., 2003; Müller, 2006). The experimental plants received the same management as the orchard plants. The local climate is subtropical, with annual mean temperatures of between $20^{\circ} \mathrm{C}$ and $21^{\circ} \mathrm{C}$ (Caviglione et al., 2000). Experimental evaluations were carried out when the plants had been in the field for 42 months (May 12, 2009). These evaluations included scoring the growth, CTV symptoms, and stem pitting intensity. For this evaluation, mature twigs were collected from the four quadrants of the plants. These twigs were peeled and scored based on the previously mentioned diagramatic scale of Meissner-Filho et al. (2002). The vegetative development was assessed based on the estimated canopy growth, which was obtained by observing the height, diameter and volume of the crown [on a scale of 1 (minimum) to 5 (maximum)]. The obtained CTV symptoms data were analyzed by the SISVAR software, version 5.1 (Ferreira, 2011). Mean comparisons of the evaluated parameters were performed using the ScottKnott test $(p<0.05)$.

\section{Results and Discussion}

Confirming the visual field observations, Xylella fastidiosa was not detected in any of the 20 samples that were assessed by PCR (data not shown). Psorosis, vein enation/woody gall, exocortis and xyloporosys symptoms were not observed in the respective indicator plants inoculated with buds from the 20 CTV sources that were evaluated (observations carried out over 12 months, data not shown).

CTV biological indexing data are presented in Table 1. Symptom evaluations showed mild to moderate vein clearing and stem pitting in all Galego lime plants inoculated with budwood from the 20 candidate trees. The RFLP analysis of the bands generated by the cleav-
Table 1 - Results of the biological index for Citrus tristeza virus (CTV) of the plants selected in orchards of the North and Northwest regions of the Paraná state and utilized controls.

\begin{tabular}{lccccc}
\hline Order & Cultivars & Counties/ Regions & $\begin{array}{c}\text { Leaf } \\
\text { chlorosis }\end{array}$ & $\begin{array}{c}\text { Stem } \\
\text { pitting }\end{array}$ & $\begin{array}{c}\text { Indicator } \\
\text { plant growth }\end{array}$ \\
\hline NE-1 & Pêra' & Nova Esperança/ NW & + & 1.0 & 2.5 \\
NE-2 & Pêra & Nova Esperança/ NW & + & 1.0 & 3.5 \\
NE-3 & Pêra & Nova Esperança/ NW & + & 1.0 & 3.5 \\
NE-4 & Pêra & Nova Esperança/ NW & + & 1.0 & 4.0 \\
NE-5 & Pêra & Nova Esperança/ NW & + & 1.0 & 4.0 \\
CS-1 & Pêra & Cruzeiro do Sul/ NW & + & 1.0 & 3.5 \\
CS-2 & Pêra & Cruzeiro do Sul/ NW & + & 1.0 & 2.5 \\
CS-3 & Pêra & Cruzeiro do Sul/ NW & + & 1.0 & 4.0 \\
CS-4 & Pêra & Cruzeiro do Sul/ NW & + & 2.0 & 3.0 \\
CS-5 & Pêra & Cruzeiro do Sul/ NW & + & 1.0 & 3.5 \\
PF-1 & Pêra & Prado Ferreira/ N & + & 2.0 & 3.0 \\
PF-2 & Pêra & Prado Ferreira/ N & + & 1.0 & 2.0 \\
PF-3 & Pêra & Prado Ferreira/ N & + & 1.0 & 3.0 \\
PF-4 & Pêra & Prado Ferreira/ N & + & 1.0 & 3.0 \\
PF-5 & Pêra & Prado Ferreira/ N & + & 1.0 & 3.0 \\
ARA-1 & Pêra & Arapongas/ N & + & 1.0 & 3.0 \\
ARA-2 & Pêra & Arapongas/ N & + & 1.0 & 2.5 \\
ARA-3 & Pêra & Arapongas/ N & + & 1.0 & 3.0 \\
ARA-4 & Pêra & Arapongas/ N & + & 2.0 & 2.5 \\
ARA-5 & Pêra & Arapongas/ N & + & 1.0 & 3.0 \\
PIAC & Pêra IAC & Mild control & + & 1.0 & 3.0 \\
CB & Capão Bonito & Severe control & +++ & 5.0 & 2.0 \\
BB & Barão B & Severe control & +++ & 4.0 & 2.0 \\
ROL & Rolândia & Severe control & +++ & 4.0 & 2.0 \\
ML & Mexican lime & Healthy control & + & 0.0 & 2.0 \\
\hline & & & & &
\end{tabular}

age of the Hinf I and Rsa I enzymes indicated that polymorphic groups existed. The cleavage by these enzymes generated various fragments, with a larger number of restriction sites for Rsa I. The dendrogram based on the polymorphic bands revealed three distinct groups: (i) group 1, formed by a Rolândia isolate that diverged from all of the other isolates; (ii) group 2, formed by other isolates used as severe controls (Capão Bonito and Barão B) and by the CS-1 and CS-3 isolates of the northwest region; and (iii) group 3, the main group, formed by all others isolates from the north and northwest regions and the Pêra IAC mild isolate (Figure 1). CS-1 and CS-3 isolates had a genetic similarity with the severe controls, even though the symptomatic evaluation of trees growing in Northwest Paraná, where plants were previously found infected by a mixture of mild to moderate CTV haplotypes (Carraro et al., 2003; Costa et al., 2010), indicated mild CTV reactions.

An ordination diagram was constructed by analyzing the main components. $35 \%$ of the total variance was explained by the two first components (component one was responsible for $22 \%$ of the total variance and component two was responsible for $13 \%$ ). A cluster formed among the isolates from selected plants with the Pêra IAC isolate, indicating genetic proximity (Figure 1). Overall, the selected trees were infected with mild CTV haplotypes and could be used as mother trees. 

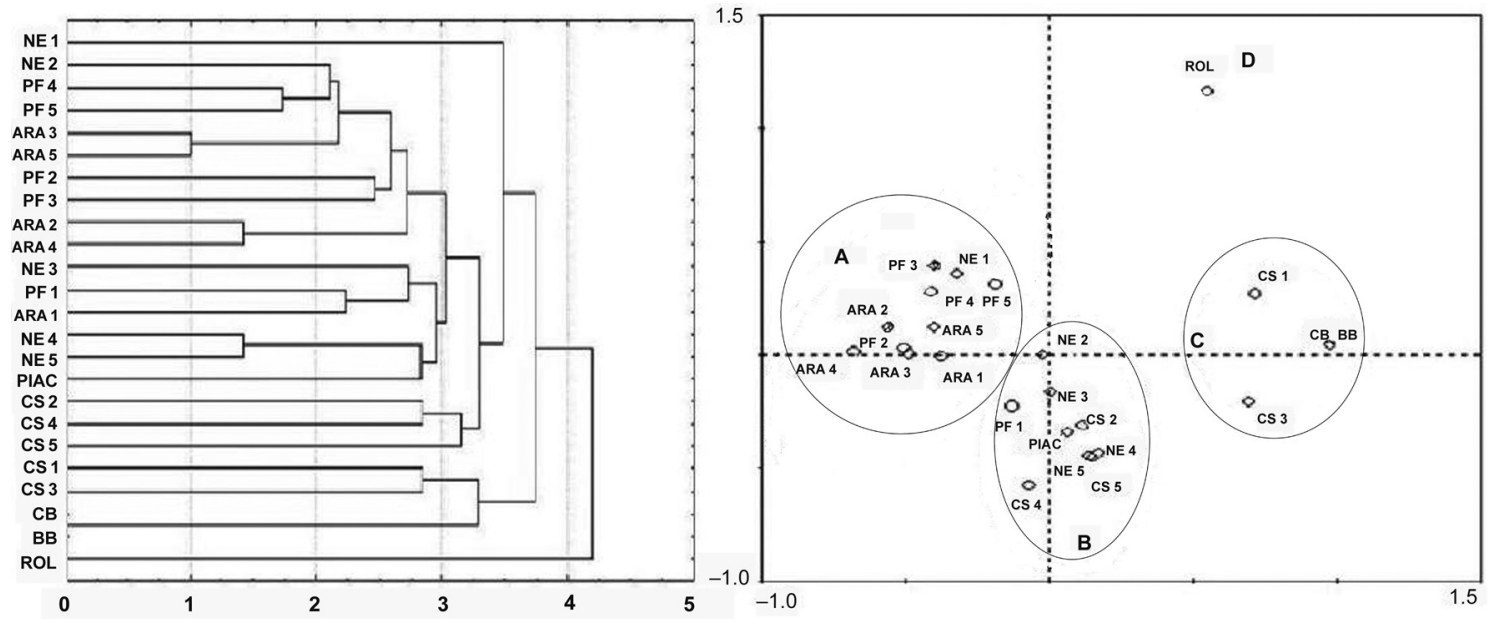

Figure 1 - Cluster dendrogram Unweighted Pair-Group Method with Arithmetic Averages (UPGMA) (I) and analysis of the main components (II) generated from a matrix of Euclidian distance, determined by the restriction fragment length polymorphism (RFLP) technique of the Citrus tristeza virus (CTV) isolates of the selected plants. The letters A, B, C and D (II) represent the formed groups.

The PCR analyses to determine the challenging inoculation efficiencies were performed every 30 days. It was possible to detect the virus in initially healthy plant tissues 90 days after aphid inoculation but not in the bud inoculated plants, in which virus became detectable only after 180 days. This may be due to either because the virus was not transferred from the bud to the recipient plants or the virus replication occurred at lower level, not being able to be detected by RT-PCR. Total RNA was extracted from all plants for further analyses seven months after inoculation.

The molecular analysis of the coat protein gene (CPG) of CTV by the SSCP technique was used to verify the stability of assayed mild protective isolates that were assessed. Therefore, this procedure aimed to verify whether the protective isolate patterns were the same or if the severe isolate was able to break down the protection. If the mild protective isolate pattern was the same after the challenge, the protective isolate was considered stable and maybe ought to protect the plant after the challenge. On the other hand, if the tested isolate was not stable or could not protect the plant against the severe isolate, it was eliminated from the preimmunization program. This type of analysis, in which the electrophoretic profiles generated by the mild and severe CTV isolates are monitored during the challenge of the severe strain(s), was used with success by Sambade et al. (2002). These authors demonstrated that the differences found in the SSCP patterns could be used to monitor the evolution of a virus population in plants that were pre-inoculated with a mild isolate and challenged by a severe one. This process could be used to evaluate the stability of the potential protective isolate. These results were confirmed by the symptom analysis of the greenhouse plants that were monitored for three years. Similarly, Licciardello et al. (2012) explained that the initial biological characterization of emerging isolates and their genetic SSCP typing could allow them to differentiate between different invading CTV virions.

The profiles obtained by SSCP analyses (Figures 2 and 3) revealed the occurrence of two to eight bands in the gels. These bands suggested the presence of one to four haplotypes in each CTV isolate. The composition or the balance of the CTV isolates within the host may be altered by factors such as the cultivar, the environment and multiple aphid infections. Thus, one CTV isolate that induces mild symptoms when biologically indexed may contain severe haplotypes that only express severe symptoms under certain conditions (VelazquezMonreal et al., 2009). In many cases, the presence of a mild isolate does not prevent the appearance of severe symptoms. Therefore, following up the preimmunization experiments for long periods of time is important permitting the discovery of mild isolates that have a lasting effect.

The electrophoretic profiles obtained from the five isolates in the municipality of Cruzeiro do Sul (northwest) were complex. Two to four haplotype mixtures were found (Figure 2-A). Amidst the five isolates listed, only the isolate Cruzeiro do Sul 1 (CS-1) did not show alterations in the SSCP pattern. However, other isolates were altered after being challenged by the severe isolate by grafting or vector inoculation. Because several authors indicated haplotype selection after aphid transmission (Broadbent et al., 1996; Sambade et al., 2002; Moreno et al., 2008), it was assumed that the tissue union would be more effective for transmitting the challenging virus than the vector inoculation (Müller and Rezende, 2004). However, in some cases, and for the plants maintained under screens, the inoculation of the challenging isolate was more effective with brown citrus aphid. This can be observed for the CS-4 and CS-5 isolates (Figure 2-A). 

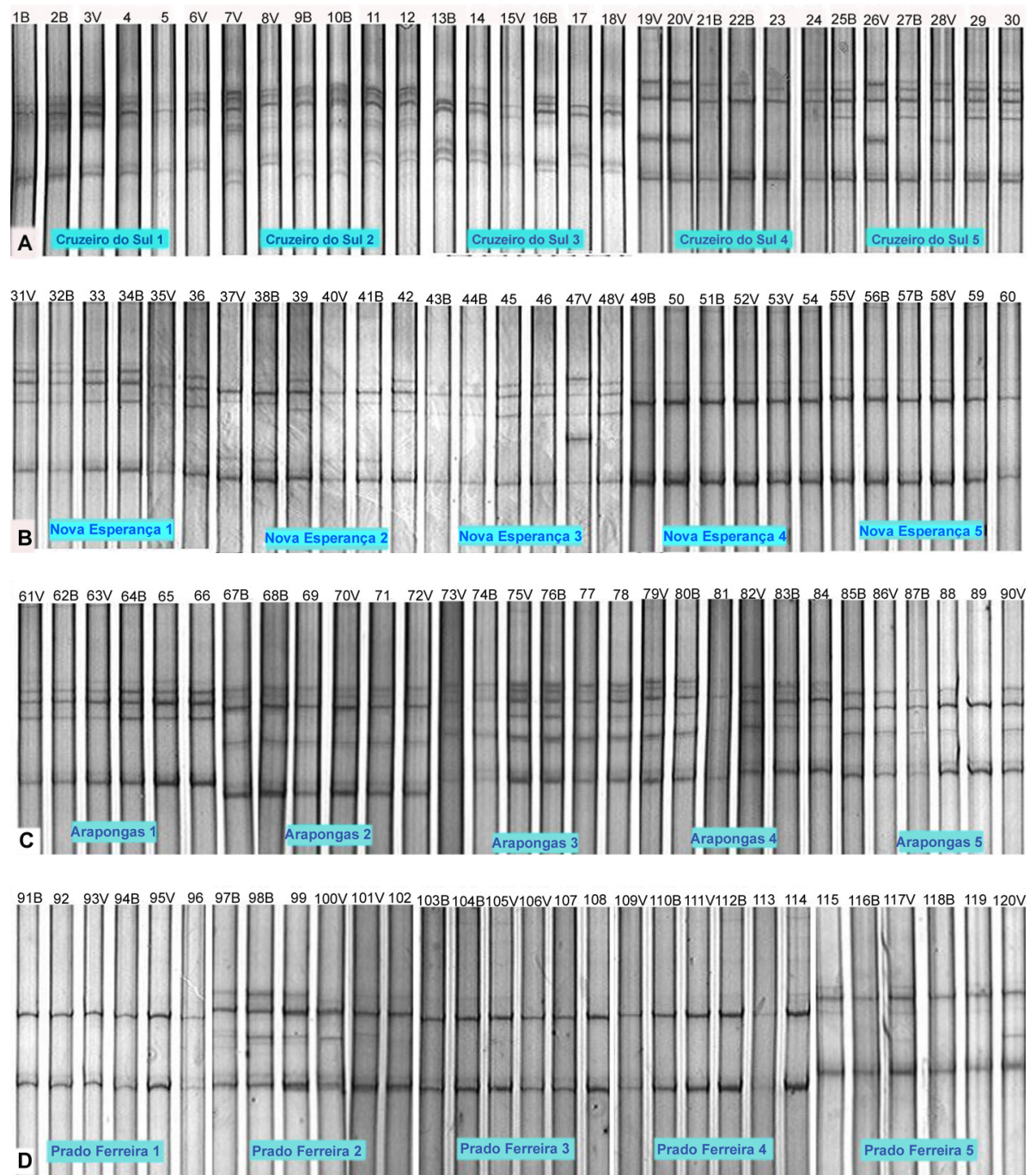

Figure 2 - Single strand conformational polymorphism (SSCP) patterns of the Citrus tristeza virus (CTV) isolates coming from selected plants of the indicated counties Cruzeiro do Sul (A), Nova Esperança (B), Arapongas (C) and Prado Ferreira (D), in polyacrylamide gel at 8 \%. Each collection of six plants represent one isolate of this region and within these isolates, the numbers and letters represent the treatments, where $\mathrm{B}$ represents the plant challenged by grafting and $\mathrm{V}$ the plant challenged by the vector. Plants kept in aphid proof screenhouse.

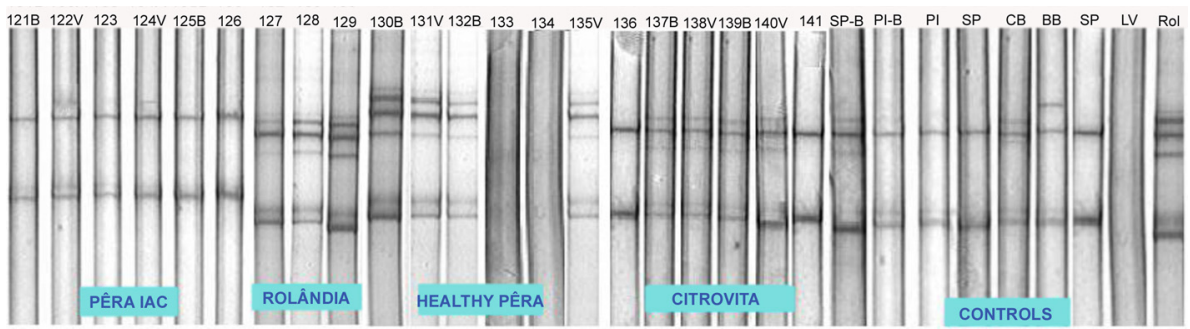

Figure 3 - Single strand conformational polymorphism (SSCP) patterns of the Citrus tristeza virus (CTV) controls: Pêra IAC, preimmunized plants and challenged with the Rolândia severe isolate through grafting (B) or by the vetor (V) (121-126); Rolândia, severe control (127-129); Healthy Pêra, virus free plants challenged by grafting (B) or by the vector (V) (130-135); Citrovita clones challenged through grafting (B) or vector (V) (136-141); Controls: SP-B, Citrovita clone challenged by grafting; PI-B, Pêra IAC challenged by grafting; PI, Pêra IAC without challenge; $\mathrm{SP}$, Citrovita clone without challenge; $\mathrm{CB}$, Capão Bonito severe isolate; $\mathrm{BB}$, Barão B severe isolate; LV, healthy plant; Rol, Rolândia severe isolate. 
In these isolates, the inoculation of the challenger isolate by the vector resulted in a band that only appeared consistently under these conditions $(19 \mathrm{~V}, 20 \mathrm{~V}, 26 \mathrm{~V}, 28 \mathrm{~V}$ and $47 \mathrm{~V})$. For these isolates, the challenging inoculation altered the electrophoretic profiles of the viral complex (relative to the unchallenged ones). Thus, it is hypothesized that these isolates may not be effective for protecting plants from the severe isolate used as a challenger.

Electrophorectic profiles of the five isolates from the municipality of Nova Esperança (northwest) were also complex, consisting in a mixture of two to three haplotypes (Figure 2-B). Nova Esperança 1, 2 and 3 (NE-1, NE-2 and NE-3) isolates had SSCP pattern alterations that resulted from the challenge by graft- or aphid transmitted severe isolates. No electrophoretic profile alterations were observed in the plants for the NE-4 and NE-5. In addition, the two isolates showed identical profiles for all plants, which suggested the presence of a common isolate that remained stable after the severe isolate challenge by both methods. The profile of these plants, however, was identical to that observed for the severe Barão B isolate (plant BB - Figure 3). This severe Barão B isolate was not evaluated under northern Paraná conditions. It did not induced severe symptoms possibly due to the tree age, to the environmental conditions of the northwest Paraná state, to the higher tolerance of the studied Pêra clone tissues or to a combination of these factors.

There were distinct profiles among the isolates from the municipality of Arapongas. However, the ARA-3 and ARA-4 isolates had the same profile, which suggested a common isolate that was not altered by the challenging inoculations (Figure 2-C). ARA-1, ARA-2 and ARA-5 isolates are distinct, but their profiles were not also altered from the challenging inoculations, which makes them potential candidates as protectors against the severe isolates. Furthermore, the SSCP analyses from the isolate profiles that originated from the municipality of Prado Ferreira (Figure 2-D) showed similarities among three of these isolates (PF-1, PF-3 and PF-4). These isolates exhibited profiles that were composed of two haplotypes and remained stable after the challenging inoculations. Thus, they were also considered to be potential protectants. The electrophorectic profiles of these isolates are identical to those of the Pêra IAC mild control. Conversely, the PF-2 and PF-5 isolates had a more complex profile that resulted from a mixture of up to four haplotypes. These isolates had altered SSCP patterns following the challenging inoculation, which indicated a possible failure in protection.

The expected results were obtained for the controls (Figure 3). The Pêra control plants, which were originally healthy and used to monitor the efficiency of the challenge inoculation either by grafting or by aphids, exhibited the profile of the severe Rolândia isolate directly collected in the field (Figure 3) or maintained under the screens (Rol). This finding demonstrates that the challenge inoculations were efficient. The severe isolate did not suffer alterations due to the elapsed period of the experiment, and its electrophorectic profiles after challenge inoculations were stable in comparison to those of the original field trees. Conversely, in comparison with the preimmunized plants, inoculation with the severe isolate resulted in the rearrangement of the electrophorectic profiles and, in many cases, induced the appearance of new bands or the deletion of pre existing bands. A similar finding was verified by Sambade et al. (2002).

The Pêra IAC control has been recognized as a stable viral complex that has a high protective capacity, but this complex was only partially stable in the present experiment and suffered SSCP band pattern alterations in two plants that were challenged by the citrus brown aphid (Figure 3, plants $122 \mathrm{~V}$ and $124 \mathrm{~V}$ ). A similar situation was observed for the Citrovita clone. However, these alterations occurred in a more accentuated form than in the SSCP electrophorectic profile of the challenged plants (Figure 3). Field plants are generally infected by a combination of CTV haplotypes that vary in their biological properties, such as pathogenicity. The dominance of a haplotype determines its complex symptomatology. Changes in the haplotype balance may alter several aspects, including the pathogenicity and the transmission efficiency of the vector (Albiach-Marti et al., 2010; Velazquez-Monreal et al., 2009).

Through the evaluation of the electrophorectic profiles generated by SSCP analysis, one can presume that the CS-1, ARA-1, ARA-2, ARA-3, ARA-4 and ARA-5 isolates have good protective capacities because they do not suffer alterations in their electrophorectic profiles after being challenged with the severe Rolândia isolate. However, the presenting profiles are distinct from those of the Pêra IAC (PF-1, PF-3 and PF-4) controls and are different from those of the severe Barão B (NE-4 and NE-5) controls. Although the characterization of the CTV isolates by sequencing the virus' coat protein gene is extensively useful, the sequence comparison of a single gene or region may reflect differences that are only found in this region. As such, this technique may not take into account the remaining genoma (Brlansky et al., 2003) that can hide the greater differences that are expressed in certain conditions.

The results obtained from the Scott-Knott test statistical analysis for stem pitting intensity, vegetative growth and tristeza symptomatology are consistent and reveal that the CS- 1 and CS-5 isolates were the only isolates that were superior for all evaluated parameters (Table 2). However, the CS-5 isolate profile was altered when challenged with the Rolândia isolate in the SSCP analysis.

The ARA-1, ARA-2, ARA-3, ARA-4 and ARA-5 isolates did not exhibit satisfactory behavior in the field experiment, which shows that alterations may have occurred in the composition of the original complex after the challenging inoculation. Sometimes, the behavior of these isolates was not different $(p<0.05)$ 
from the Rolândia isolate (Table 2). Because the electrophoretic profile of these plants before and after challenging were similar to those observed for the Rolândia severe isolate, the SSCP molecular analysis of the CPG did not support this hypothesis. In addition, the CTV isolates that infect a plant are not homogenously distributed to all plant tissues (d'Urso et al., 2000). The buds used as an inoculum in the grafting process may not contain the entire viral complex of the donor plant. Furthermore, the composition or balance of the CTV isolates within the host may be altered by the viral genome interaction, citrus host variety, environment conditions and by multiple aphid infections. Thus, a CTV isolate that shows mild symptoms when indexed biologically may contain one or more severe haplotypes that could express severe symptoms under certain conditions (Brlansky et al., 2003; Folimonova et al., 2010; Roy and Brlansky, 2009; Velazquez-Monreal et al., 2009).

Transmission by viruliferous aphids may segregate the haplotypes of the virus and modify the genetic composition of a given CTV isolate (Velazquez-Monreal et al., 2009). In fact, this process may explain the high genetic variability observed under field conditions and the

Table 2 - Means observed in the field for the studied parameters of the groups of 6 plants that compose the isolates, submitted or not to challenge with the Rolândia severe isolate, through grafting or vector.

\begin{tabular}{lccc}
\hline \multicolumn{4}{c}{ Evaluated parameters (Means) } \\
\hline Isolate & $\begin{array}{c}\text { Stem pitting } \\
\text { intensity }\end{array}$ & $\begin{array}{c}\text { Vegetative } \\
\text { development }\end{array}$ & $\begin{array}{c}\text { Leaf } \\
\text { symptoms }\end{array}$ \\
\hline CS-1 & $1.25 \mathrm{a}$ & $4.67 \mathrm{a}$ & $0.25 \mathrm{a}$ \\
PF-5 & $1.45 \mathrm{a}$ & $3.00 \mathrm{~b}$ & $0.64 \mathrm{a}$ \\
PF-2 & $1.50 \mathrm{a}$ & $3.00 \mathrm{~b}$ & $0.30 \mathrm{a}$ \\
PF-3 & $1.58 \mathrm{a}$ & $3.00 \mathrm{~b}$ & $0.25 \mathrm{a}$ \\
NE-5 & $1.60 \mathrm{a}$ & $3.10 \mathrm{~b}$ & $0.50 \mathrm{a}$ \\
NE-1 & $1.73 \mathrm{a}$ & $3.27 \mathrm{~b}$ & $0.45 \mathrm{a}$ \\
NE-4 & $1.78 \mathrm{a}$ & $2.67 \mathrm{~b}$ & $0.78 \mathrm{a}$ \\
CS-5 & $1.82 \mathrm{a}$ & $3.73 \mathrm{a}$ & $0.64 \mathrm{a}$ \\
LV & $1.82 \mathrm{a}$ & $2.82 \mathrm{~b}$ & $1.27 \mathrm{a}$ \\
CS-2 & $1.89 \mathrm{~b}$ & $3.33 \mathrm{~b}$ & $0.89 \mathrm{a}$ \\
ARA-5 & $2.00 \mathrm{~b}$ & $2.80 \mathrm{~b}$ & $0.30 \mathrm{a}$ \\
CS-4 & $2.00 \mathrm{~b}$ & $4.10 \mathrm{a}$ & $0.60 \mathrm{a}$ \\
ARA-1 & $2.00 \mathrm{~b}$ & $3.17 \mathrm{~b}$ & $0.50 \mathrm{a}$ \\
ARA-2 & $2.11 \mathrm{~b}$ & $2.89 \mathrm{~b}$ & $0.33 \mathrm{a}$ \\
SP & $2.11 \mathrm{~b}$ & $2.78 \mathrm{~b}$ & $0.56 \mathrm{a}$ \\
PF-4 & $2.20 \mathrm{~b}$ & $3.00 \mathrm{~b}$ & $0.50 \mathrm{a}$ \\
P IAC & $2.20 \mathrm{~b}$ & $3.00 \mathrm{~b}$ & $1.00 \mathrm{a}$ \\
PF-1 & $2.20 \mathrm{~b}$ & $2.60 \mathrm{~b}$ & $0.40 \mathrm{a}$ \\
CS-3 & $2.30 \mathrm{~b}$ & $4.30 \mathrm{a}$ & $1.00 \mathrm{a}$ \\
NE-2 & $2.36 \mathrm{~b}$ & $2.82 \mathrm{~b}$ & $0.64 \mathrm{a}$ \\
NE-3 & $2.55 \mathrm{c}$ & $2.91 \mathrm{~b}$ & $0.91 \mathrm{a}$ \\
ARA-3 & $2.78 \mathrm{c}$ & $2.89 \mathrm{~b}$ & $0.33 \mathrm{a}$ \\
ARA-4 & $3.22 \mathrm{~d}$ & $2.33 \mathrm{~b}$ & $0.33 \mathrm{a}$ \\
ROL & $3.78 \mathrm{~d}$ & $1.78 \mathrm{~b}$ & $3.11 \mathrm{~b}$ \\
\hline
\end{tabular}

${ }^{*}$ Means in the columns followed by different letters are different (Scott-Knott test, $p<0.05), C V=32 \%$. observed pathogenicity alterations (Ayllón et al., 1999; Brlansky et al., 2003; Velazquez-Monreal et al., 2009). The field experiment evaluations showed that challenge inoculation by tissue union with the severe isolate lead to severe tristeza symptoms with high stem pitting and leaf symptom scores and low vegetative development scores (Table 2).

The transmission of CTV through the vector was first detected in the monitored plants. A greater number of plants had altered SSCP electrophorectic profiles in the plants inoculated by the vector than in the plants inoculated by grafting under screened conditions. However, these results were contradictory in the field. When these data were analyzed with the Scott-Knott test $[p<$ 0.05 (Table 3)], only the challenge inoculation by grafting showed significant differences for all evaluated parameters. In contrast, the treatments that were inoculated by the vector were not different than the non-inoculated treatments.

Müller (1996) performed tests to study the protective effects of the mild CTV isolates in Pêra sweet orange, Mexican lime and Ruby Red grapefruit. They found that preimmunization offered long lasting satisfactory protection when the plants were exposed to natural or experimental aphid challenges. However, a breakdown in protection could occur when the plants were challenged by grafting.

This finding is in agreement with the results found by Brlansky et al. (2003), in which severe strains that were part of a mild viral complex were transmitted by a vector. Inverse results were observed by Velazquez-Monreal et al. (2009). Additionally, using single transmissions by the brown citrus aphid as a tool for separation, the presence of severe haplotypes hidden in mild isolates was found in isolates derived from Australia, Florida and France. The genetic profiles of three Florida CTV isolates were studied in three citrus host species. The profiles of these isolates were not altered by graft transmission (Broadbent et al., 1996; Brlansky et al., 2003; Roy and Brlansky, 2009). Thus, it is presumed that the small time between the vector inoculation and the collection of the samples for the molecular analysis (in comparison with the exposition time of the plants in the field) leads to the rapid observation of the electrophorectic profiles of the vector challenged plants.

Table 3-Observed means for the effect of the challenging inoculation method with the severe isolate, on the evaluated parameters: stem pitting intensity, vegetative development and tristeza leaf symptoms.

\begin{tabular}{lccc}
\hline \multicolumn{4}{c}{ Evaluated parameters* } \\
\hline Inoculation method & $\begin{array}{c}\text { Stem pitting } \\
\text { intensity }\end{array}$ & $\begin{array}{c}\text { Vegetative } \\
\text { development }\end{array}$ & $\begin{array}{c}\text { Leaf } \\
\text { symptoms }\end{array}$ \\
\hline Grafting & $3.02 \mathrm{a}$ & $2.58 \mathrm{a}$ & $1.81 \mathrm{a}$ \\
Vector & $1.85 \mathrm{~b}$ & $3.09 \mathrm{~b}$ & $0.41 \mathrm{~b}$ \\
Without inoculation & $1.75 \mathrm{~b}$ & $3.32 \mathrm{~b}$ & $0.30 \mathrm{~b}$ \\
\hline
\end{tabular}

${ }^{*}$ Means in the columns followed by different letters are different (Scott-Knott test, $p<0.05), C V=25 \%$. 
Tissue union inoculation most likely allowed the transmission of the entire potentially mild protective viral complex to the preimmunized plants. However, a greater period of time between distribution and equilibrium may be required for the establishment of the viral complex components in inoculated plants. This longer time frame could result in a more precise reproduction of the original virus complex that was inoculated in the plant. Thus, a severe isolate such as the Rolândia isolate would require a greater period of time to become established and stabilized. In addition, it would take more time for the inoculated plants to express severe symptoms that point to the breakdown of protection. Currently, the plants challenged by the vector have received only part of the viral complex strain, which constitutes a new desinbalance complex. This new viral complex may multiply rapidly. However, with the time that elapsed in the field, this viral complex may occur as a re-equilibrium of the new complex that does not present the same severity that was observed in the original complex. Similar observations were found in the work of Sambade et al. (2002), Brlansky et al. (2003) and Velazquez-Monreal et al. (2009).

The CS-1 isolate, which is the most promising among the evaluated isolates, received high vegetative development score, lack of symptoms, very mild pitting (Table 2) in good agreement with SCCP data. It behaved better than Pêra IAC and Citrovita mild strain clones and strengthen the idea that the protecting isolates should be selected in the area where they will be used to achieve the best preimmunization results.

\section{References}

Albiach-Marti, M.R.; Robertson, C.; Gowda, S.; Tatineni, S.; Belliure, B.; Garnsey, S.M.; Folimonova, S.Y.; Moreno, P.; Dawson, W.O. 2010. The pathogenicity determinant of Citrus tristeza virus causing the seedling yellows syndrome maps at the 3 '-terminal region of the viral genome. Molecular Plant Pathology 11: 55-67.

Ayllón, M.A.; Rubio, L.; Moya, A.; Guerri, J.; Moreno, P. 1999. The haplotype distribution of two genes of citrus tristeza virus is altered after host change or aphid transmission. Virology 255: 32-39.

Beidler, L.L.; Hilliard, P.R.; Rill, R.L. 1982. Ultrasensitive staining of nucleic acids with silver. Analytical Biochemistry 126: 374380.

Brlansky, R.H.; Damsteegt, V.D.; Howd, D.S.; Roy, A. 2003. Molecular analyses of Citrus tristeza virus subisolates separated by aphid transmission. Plant Disease 87: 397-401.

Broadbent, P.; Brlansky, R.H.; Indsto, J. 1996. Biological characterization of Australia isolates of Citrus tristeza virus and separation by single aphid transmissions. Plant Disease 80: 329-333.

Carraro, B.P.; Nunes, W.M.C.; Corazza-Nunes, M.J.; Machado, M.A.; Stach-Machado, D.R. 2003. Avaliação de complexos do Citrus tristeza virus da região Norte do Paraná por meio de testes imunológicos e SSCP do gene da capa protéica = Evaluation of the Citrus tristeza virus complex occurrence in Northern Paraná State through immunological assay and SSCP. Acta Scientiarum 25: 269-273.
Carvalho, S.A.; Machado, M.A.; Baptista, C.R.; Müller, G.W.; Silverio, J.L. 1997. Biological characterization of isolates of Citrus tristeza virus. Fitopatologia Brasileira 22: 79-84 (in Portuguese, with abstract in English).

Carvalho, S.A.; Machado, M.A.; Müller, G.W. 2003. Evaluation of indicator plants and rootstocks in biological indexing of xiloporose viroid in citrus. Laranja 24: 145-155 (in Portuguese, with abstract in English).

Caviglione, J.H.; Kiihl, L.R.B.; Caramori, P.H.; Oliveira, D. Climatic maps of Paraná - IAPAR 2000. Available at http://www.iapar. $\mathrm{br} /$ modules/conteudo/conteudo.php?conteudo $=677$ [Accessed Aug. 20, 2008] (in Portuguese, with abstract in English).

Corazza-Nunes, M.J.; Machado, M.A.; Müller, G.W.; StachMachado, D.R.; Souza, A.A.; Nunes, W.M.C. 2001. Evaluation of citrus tristeza virus (CTV) complexes in preimmunized Marsh seedless grapefruit. Summa Phytopathologica 27: 11-16.

Costa, A.T.; Nunes, W.M.C; Corazza, M.J.; Zanutto, C.A.; Müller, G.W. 2010. Biological and molecular characterization of isolates of Citrus tristeza virus with potential for use in preimmunization programs. Summa Phytopathologica 36: 81-82 (in Portuguese, with abstract in English).

D'Urso, F.; Ayllón, M.A.; Rubio, L.; Sambade, A.; Hermoso De Mendonza, A.; Guerri, J.; Moreno, P. 2000. Contribution of uneven distribution of genomic RNA variants of Citrus tristeza virus (CTV) within the plant to change in the viral population following aphid transmission. Plant Pathology 49: 288-294.

Ferreira, D.F. 2011. Sisvar: a computer statistical analysis system. Ciência e Agrotecnologia 35: 1039-1042.

Folimonova, S.Y.; Robertson, C.J.; Shilts, T.; Folimonov, A.S.; Hilf, M.E.; Garnsey, S.M.; Dawson, W.O. 2010. Infection with strains of Citrus tristeza virus does not exclude superinfection by other strains of the virus. Journal of Virology 84: 1314-1325.

Greve, A.; Prates, H.S.; Müller, G.W. 1991. Production of certified budwood of citrus in São Paulo state. p. 302-317. In: Rodriguez, O.; Viegas, F. Citricultura Brasileira v. 1. 2ed. Fundação Cargill, Campinas, SP, Brazil (in Portuguese, with abstract in English).

Herrera-Isidrón, L.; Ochoa-Sánchez, J.C.; Rivera-Bustamante, R.; Martínez-Soriano, J.P. 2009. Sequence diversity on four ORFs of citrus tristeza virus correlates with pathogenicity. Virology Journal 6: 116.

Licciardello, G.; Raspagliesi, D.; Bar-Joseph, M.; Catara, A. 2012. Characterization of isolates of Citrus tristeza virus by sequential analyses of enzyme immunoassays and capillary electrophoresis-single-strand conformation polymorphisms. Journal of Virological Methods 181: 139-147.

Meissner-Filho, P.E.; Soares-Filho, W.S.; Velame, K.V.C.; Diamantino, E.; Diamantino, M.S.A. 2002. Reaction of hybrid rootstocks to Citrus tristeza virus. Fitopatologia Brasileira 27: 312-315 (in Portuguese, with abstract in English).

Moreno, P.; Ambrós, S.; Albiach-Marti, M.R.; Guerri, J.; Peña, L. 2008. Citrus tristeza virus: a pathogen that changed the course of the citrus industry. Molecular Plant Pathology 9: 251-268.

Müller, G.W. 1996. Brown citrus aphid and Citrus tristeza in Brazil. Laranja 17: 292-295 (in Portuguese, with abstract in English).

Müller, G.W.; Rezende, J.A.M. 2004. Preimmunization: applications and perspectives in Virus Disease Control. p. 361-395. In: Naqvi, S.A.M.H., ed. Diseases of fruits and vegetable-diagnosis and management 1. Kluwer, Amsterdam, Netherlands. 
Müller, G.W.; Targon, M.L.P.N.; Machado, M.A. 1999. Thirty years of preimmunized "Pêra IAC" sweet orange in the citriculture of São Paulo state, Brazil. Laranja 20: 399-408.

Roy, A.; Brlansky, R.H. 2009. Population dynamics of a Florida Citrus tristeza virus isolate and aphid-transmitted subisolates: Identification of three genotypic groups and recombinants after aphid transmission. Phytopathology 99: 1297-1306.

Salibe, A.A.; Tubelis, A.; Crocomo, O.J.; Gallo, L.A.; Oliveira, E.T. 1992. The Citrovita clone: a plant matrix of citrus. Laranja 13: 261-273 (in Portuguese, with abstract in English).

Sambade, A.; Rubio, L.; Garnsey, S.M.; Costa, N.; Müller, G.W.; Peyrou, M.; Guerri, J.; Moreno, P. 2002. Comparison of viral RNA populations of pathogenically distinct isolates of Citrus tristeza virus: application to monitoring cross-protection. Plant Pathology 51: 257-265.
Sambrook, J.; Fritsh, J.; Maniatis, T. 1989. Molecular Cloning: A Laboratory Manual. 2ed. Cold Spring Harbor Laboratory Press, New York, NY, USA.

Valverde, R.A.; Nameth, S.T.; Jordan, R.L. 1990. Analysis of double strand RNA for plant virus diagnosis. Plant Disease 71: 255-258.

Velazquez-Monreal, J.J.; Mathews, D.M.; Dodds, J.A. 2009. Segregation of distinct variants from Citrus tristeza virus isolate SY568 using aphid transmission. Phytopathology 99: 11681176. 